R. E. Koller, G. Piskoty, M. Zgraggen

\title{
Scheme of the Failure Analysis Taking the Example of Profile Wire Breaks in the Support Cable of a Cable Car System
}

\section{Systematik der Schadensanalyse am Beispiel von Profildrahtbrüchen im Tragseil einer Seilbahnanlage}

Received: October 22, 2015 Accepted: November 05, 2015

\section{Abstract}

Cable car systems are predominantly used in the Alpine Region for the transportation of passengers and goods. During operation, their components are subjected to environmental influences as well as to static and dynamic loads. Even if standards, measurements, experimental tests, periodic inspections, and maintenance are considered, a component failure can not be entirely excluded. It is for that reason that cases of damage in the cable car industry are clarified based on systematic analyses aiming at prevention and an increase in security.
Eingegangen: 22. Oktober 2015 Angenommen: 05. November 2015

\section{Kurzfassung}

Seilbahnanlagen werden überwiegend in Alpenräumen zum Personen- und Materialtransport eingesetzt. Deren Komponenten unterliegen im Betrieb neben Umwelteinflüssen auch statischen und dynamischen Beanspruchungen, Bauteilversagen kann auch mit Berücksichtigung von Normen, Messungen, experimentellen Versuchen, periodischen Inspektionen und Wartung nie ganz ausgeschlossen werden. Daher werden Schadensfälle - wie in anderen Bereichen - zu Prävention und Erhöhung der Sicherheit auch in der Seilbahnbranche durch systematische Analysen abgeklärt

\section{Authors:}

Roland E. Koller, Gabor Piskoty Empa, Eidgenössische Materialprüfungs- und

Forschungsanstalt, Überlandstrasse 129, $\mathrm{CH}-8600$ Dübendorf

e-mail: roland.koller@empa.ch, gabor.piskoty@empa.ch

Markus Zgraggen IWT, Institut für Werkstofftechnologie AG, Richtistrasse 15, CH-8304

Wallisellen, e-mail: markus.zgraggen@iwt-institut.ch

The approach for the identification of the underlying causes of a case of failure is presented using the example of a spectacular incident in 2004 where all external profile wires of a support cable of a 100 passenger aerial tramway broke during operation.

A precautionary and thorough preservation of evidence, detailed examinations of the subject components, clarifications of the operating history of the system, as wel as an eventual identification of a probable damage process supported by examination findings are essential steps of this ap proach.

The findings of such evaluations are the basis for recommendations regarding testing and construction of further systems, their operation, maintenance, and inspections with a focus on damage prevention.

\section{Introduction}

The following section summarizes an incident on the cable car Mürren - Birg (Switzerland) which occurred on December 29th 2004 [1-3].

The cabin on track 1, carrying 53 passengers and comprising the support cables A and $B$, went up the mountain when the cable car personnel heard a loud popping. As the noise was of unclear origin, the system was immediately stopped and the rail was visually checked with the help of a helicopter. Findings indicate that all external profile wires of support cable B were broken at a distance of approx $60 \mathrm{~m}$ from the top station (Fig. 1). All passengers were evacuated by a helicopter and the cable car's operation was stopped. Both support cables of the subject track were partially relieved by allowing them approx. $11 \mathrm{~m}$ of slack as well as by lifting the tensioning weight in the valey station for security reasons.
Anhand eines spektakulären Ereignisses im Jahre 2004, bei dem während des Betriebes alle außen liegenden Profildrähte eines Tragseils einer 100-Personen-Pendelbahn brachen, wird die Vorgehensweise zur Abklärung der für das Versagen verantwortlichen Ursachen vorgestellt.

Wesentliche Schritte dabei sind eine sorgfältige, vorsorgliche Beweissicherung, detaillierte Untersuchungen an den schadhaften Komponenten, Abklärungen zur Betriebsgeschichte der Anlage sowie letztlich eine durch Untersuchungsbefunde gestützte Identifizierung eines wahrscheinlichen Schädigungsprozesses.

Mit Fokus auf die Schadensprävention flieBen die Erkenntnisse derartiger Abklärungen schliesslich in Empfehlungen hinsichtlich Überprüfung und Konstruktion weiterer $\mathrm{An}$ lagen, Betrieb, Wartung und Inspektionen ein.

\section{Einleitung}

An der Pendelbahn Mürren - Birg (Schweiz) ereignete sich am 29. Dezember 2004 ein im Folgenden zusammengefasster Vorfall [1-3].

Die mit 53 Personen besetzte Kabine der Fahrbahn 1, bestehend aus den Tragseilen A und $B$, fuhr bergwärts, als das Bahnpersonal der Bergstation ein lautes Knallgeräusch wahrnahm. Da die Ursache dafür unklar war, wurde die Anlage sofort gestoppt und die Bahn mit Hilfe eines Hubschraubers visuell überprüft. Es zeigte sich, dass ca. $60 \mathrm{~m}$ von der Bergstation entfernt alle äusseren Profildrähte des Tragseiles B gerissen waren (Bild 1). Alle Fahrgäste wurden mit einem Hubschrauber evakuiert und der Betrieb der Pendelbahn wurde eingestellt. Aus Sicherheitsgründen wurden beide Tragseile der schadhaften Fahrbahn durch Nachlassen um ca. $11 \mathrm{~m}$ sowie durch Anheben des Spanngewichtes in der Talstation teilentlastet 


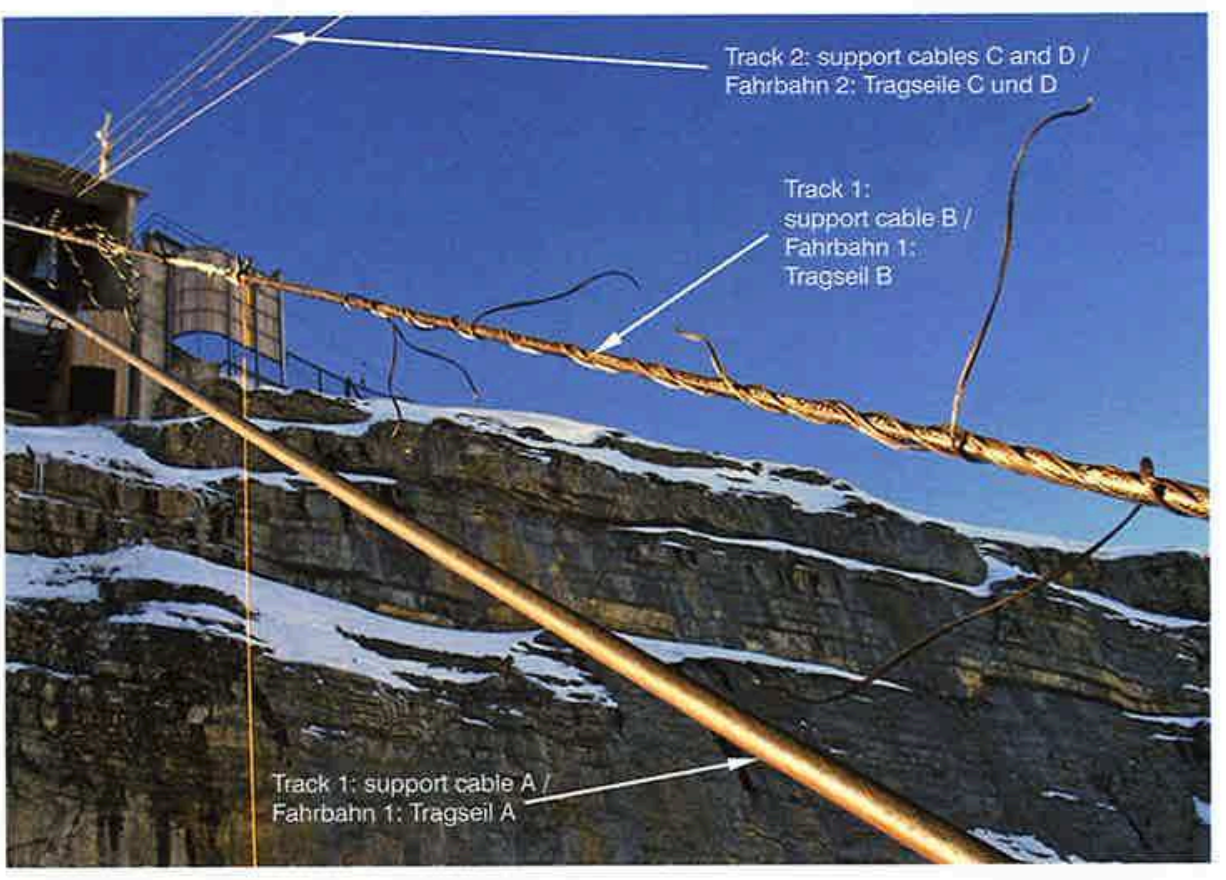

Fig. 1: Support cable $B$ showing a cracked sheath in a distance of about $60 \mathrm{~m}$ from the top station (the picture was taken after the partial relief of the support cables $A$ and $B$ )

Bild 1: Tragseil B mit gerissenem Mantel ca. $60 \mathrm{~m}$ von der Bergstation entfernt (Aufnahme nach Teilentlastung der Tragseile $A$ und $B$ )

\section{Scheme of the Damage Analysis}

The damage case was clarified based on internationally recognized guidelines and recommendations [4-7]. The approach can be subdivided into the following phases [5]:

- Preservation of evidence (anamnesis)

- Information on the installation and the case of damage (history)

- Determination of the type of fracture (diagnosis)

- Hypotheses on the cause of the damage and its evolution

- Investigations aiming at supporting or refuting the hypotheses (tests)

- Precautionary recommendations (therapy)

\section{Systematik bei Schadensanalysen}

Die Abklärung des Schadensfalles stützte sich auf international anerkannte Richtlinien und Emprehlungen [4-7]. Die Vorgehensweise lässt sich in folgende Phasen unterteilen [5]:

- Beweissicherung (Anamnese)

- Informationen zur Anlage und zum Schadensfall (Lebenslauf)

- Ermittlung der Bruchart (Diagnose)

- Hypothesen zur Schadensursache und -entwicklung

- Untersuchungen zur Bestätigung oder Widerlegung der Hypothesen (Versuche)

- Vorbeugende Empfehlungen (Therapie)
A comprehensive clarification of the dam age was ensured based on the creation of a team of specialists from the relevant fields of expertise: cable car technology, damage analysis, materials science, fracture mechanics, corrosion chemistry, and nondestructive material testing.

\section{On-Site Survey -}

\section{Preservation of Evidence}

As with many cases of damage, the installation parameters and boundary conditions possibly relevant for the clarification of the damage could not be determined at the beginning of the investigation, Therefore in-depth precautionary surveys were per
Mit der Bildung eines Spezialistenteams aus den betroffenen Fachbereichen Seilbahntechnik, Schadensanalytik, Werkstoffkunde Bruchmechanik, Korrosionschemie und zerstörungsfreie Werkstoffprüfung wurde eine umfassende Schadensabklärung sichergestellt.

\section{Bestandsaufnahme vor Ort -}

\section{Beweissicherung}

Wie bei vielen Schadensfällen war zu Be ginn der Untersuchungen nicht abschätzbar welche Anlageparameter und Randbedingungen bei der Schadensabklärung relevant sein könnten. Daher wurden vor Ort vorerst detaillierte, vorsorgliche Bestandsaufnahmen

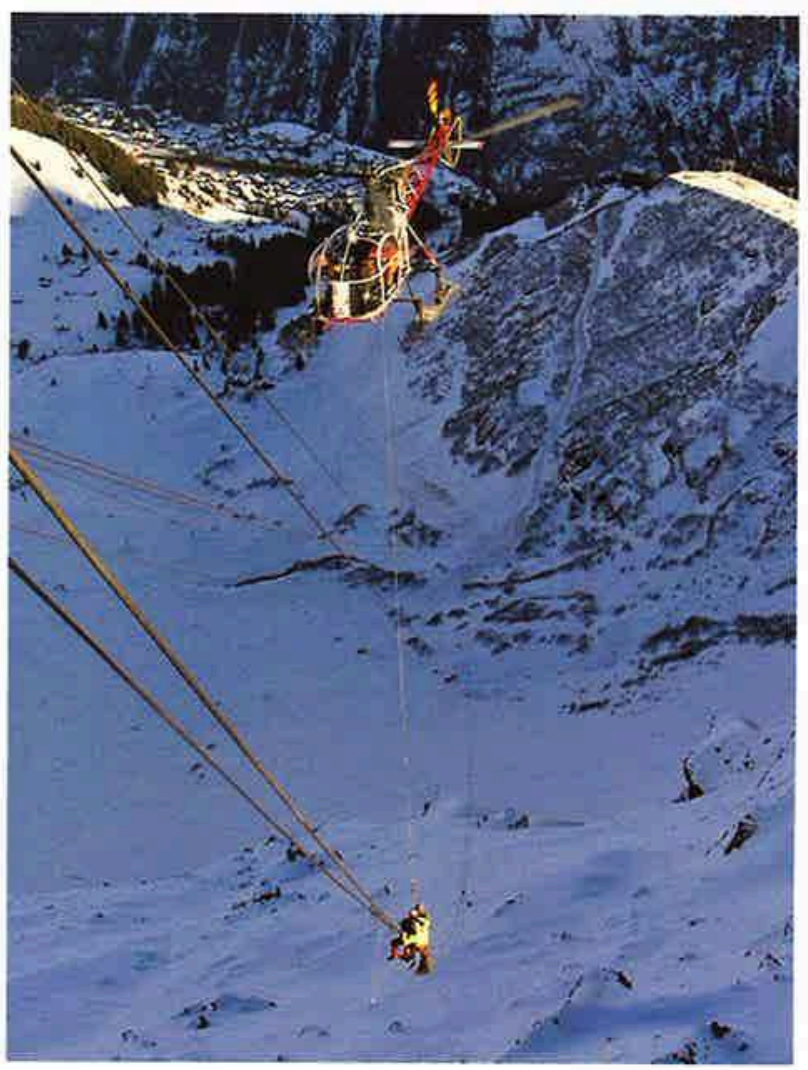

Fig. 2: Documentation and measurements in the damaged area of support cable $B$ Bild 2: Dokumentation und Messungen im Schadensbereich von Tragseil B 
formed on-site to begin with. These surveys covered the visual inspection and photodition of both the defective support cable (Fig, 2) and the installation in the top station, In addition to that, the area below the damaged area was searched for potential flung off profile wire fragments.

Those installation parameters which could no longer be reconstructed after removing the support cables were obtained by measurements and logged. The focus was on measuring the support cables $A$ and $B$ of track 1. For comparison purposes, measurements were partially also performed on the support cables $\mathrm{C}$ and $\mathrm{D}$ of track 2

\section{Information on the Installation}

When developing damage hypotheses and during the analysis of damage causes and damage progression, installation-specific information can provide crucial indications. It was for this reason that a maximum of information on the cable car's history was gathered.

The given installation is a "classic" doubletrack aerial tramway with two cables build in 1965. Both tracks consist of two support cables, respectively, These cables are tensioned in the valley station using a shared tensioning weight, The support cables are individually anchored in the valley station by means of a bollard. Since the installation of the system, several documented revisions and modifications have been performed. In addition to that, the support cables are shifted towards the valley by approx, $20 \mathrm{~m}$ about every seven years in order to relieve those cable areas which are subjected to increased bending loads with pylons and station bearings, Thus, an optimal load distribution on the cable and an increased service life of the cable can be achieved.

The support cables were manufactured in 1964 as locked coil ropes (Fig. 3) from rolled, cold-drawn steel wires containing durchgeführt. Diese umfassten die visuelle Begutachtung und fotografische Dokumentation der sich darbietenden Situation am schadhatten Tragseil (Bild 2) und des Anlagezustandes in der Bergstation. Zudem wurde das Gelände unterhalb des Schadensbereiches nach möglichen, weggeschleuderten Profildraht-Bruchstücken abgesucht

Diejenigen Anlageparameter, welche nach der Demontage der Tragseile nicht mehr rekonstruierbar waren, wurden messtechnisch erfasst und protokolliert. Im Vordergrund standen Messungen an den Tragseilen A und $B$ der Fahrbahn 1 und zu Vergleichszwecken teilweise auch an den Tragseilen C und D der Fahrbahn 2,

\section{Angaben zur Anlage}

Beider Erarbeitung von Schadenshypothesen Schadensursachen und -verläufen können anlagespezifische Informationen entscheidende Hinweise liefern. Aus diesem Grunde wurde der Lebenslauf der Seilbahn möglichst umfassend zusammengetragen.

Bei der vorliegenden Anlage handelt es sich um eine "klassische", zweispurige ZweiseilPendelbahn, welche im Jahre 1965 erbaut wurde. Beide Fahrbahnen bestehen je aus zwei Tragseilen, die in der Talstation mit einer gemeinsamen Spannmasse gespann werden. In der Bergstation sind die Tragseile einzeln mit Hilfe je eines Pollers verankert Seit der Erstellung der Anlage wurden mehrere dokumentierte Revisionen und Modifikationen durchgeführt. Zudem wurden etwa alle sieben Jahre die Tragseile um ca. 20 m talwärts verschoben, um die bei Stützen- und Stationsauflagern erhöht biegebeanspruchten Seilbereiche zu entlasten. Damit kann eine gleichmäßigere Seilbeanspruchung und somit eine erhöhte Seillebensdauer erreicht werden.

Die Tragseile wurden als einmal verschlossene Spiralseile (Bild 3) aus gewalzten, kaltgezogenen Stahldrähten mit $0.6 \%$ Kohlenstof

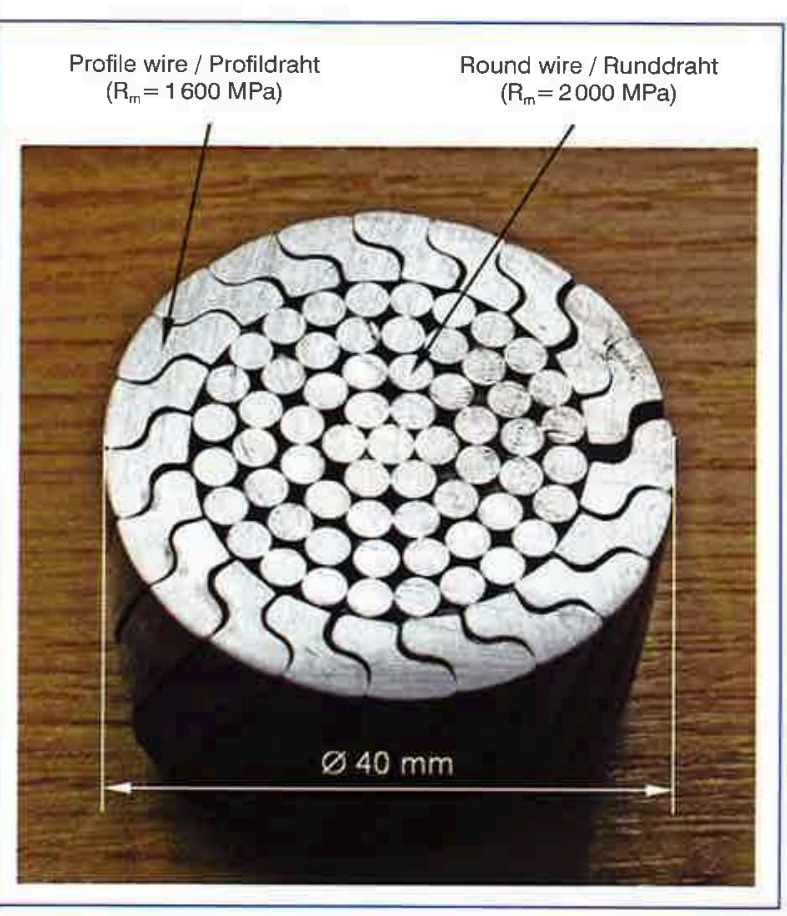

Fig. 3: Cross section of the support cables $A, B, C$, and $D$

Bild 3: Querschnitt der Tragseile $A, B, C$ und $D$
$0.6 \%$ carbon. The rope specifications were completely available. In new condition, they complied with the applicable commissioning requirements. The last routinely performed, non-destructive, magneto-inductive test of the support cable was conducted in April 2004, a few months before the damaging incident. During this test, neither wire breaks nor other damages were detected in support cable B.

\section{Investigations on the Support Cables and in the Top Station}

\subsection{Visual Findings}

The visual evaluation of the defective section of the rope was performed on the partially relieved rope on-site (-ig. 2) as well as on the detached rope section with an approx. length of $24 \mathrm{~m}$ in the Empa laboratory in Dübendorf. The location and the defor-

Pract, Metallogr. 53 (2016) 12 im Jahre 1964 hergestellt. Die seilspezifischen Kenndaten waren vollständig vorhanden und entsprachen im Neuzustand den bei der Inbetriebnahme geltenden Anforderungen. Die letzte, routinemäßig durchgeführte, zerstörungsfreie, magnetinduktive Tragseilprüfung fand im April 2004, wenige Monate vor dem Schadensereignis statt. Im Tragseil B wurden dabei weder Drahtbrüche noch sonstige $\mathrm{Be}$ schädigungen festgestellt.

\section{Untersuchungen an den Tragseilen und in der Bergstation}

\subsection{Visuelle Befunde}

Die visuelle Beurteilung des schadhaften Seilabschnittes erfolgte einerseits am teilentlasteten Seil vor Ort (Bild 2), andererseits am herausgetrennten, ca, $24 \mathrm{~m}$ langen Seilabschnitt im Labor der Empa in Dübendorf. Beurteilt wurden primär Lage und Verformung 


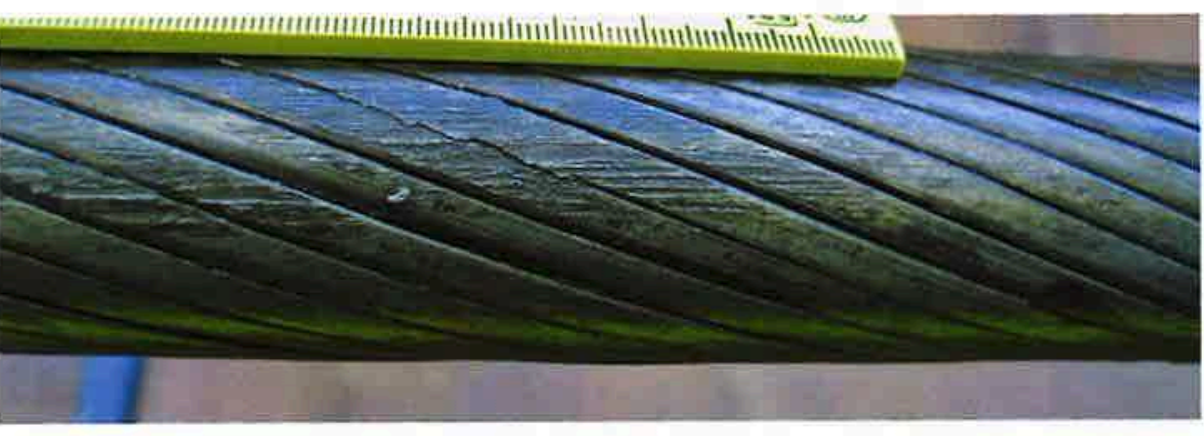

Fig. 4: Friction marks with scale-like build-ups on the support cable $B$ Bild 4: Reibspuren mit schuppenartigen Auftragungen am Tragseil $B$

mation of the broken profile wires as well as the condition of the surface of the rope sections adjacent to the area of damage were primarily evaluated.

In the area of contact with the car's track rollers, these intact sections are characterized by a bare, shiny surface and, on the opposite side, by a rust-brown, normal corrosion condition with grease-like deposits. The cable's surface did neither reveal any color pigments of the car's running gear nor signs of excessive wear, However, on the border of the contact area of the car's track rollers in the intact section of the cable

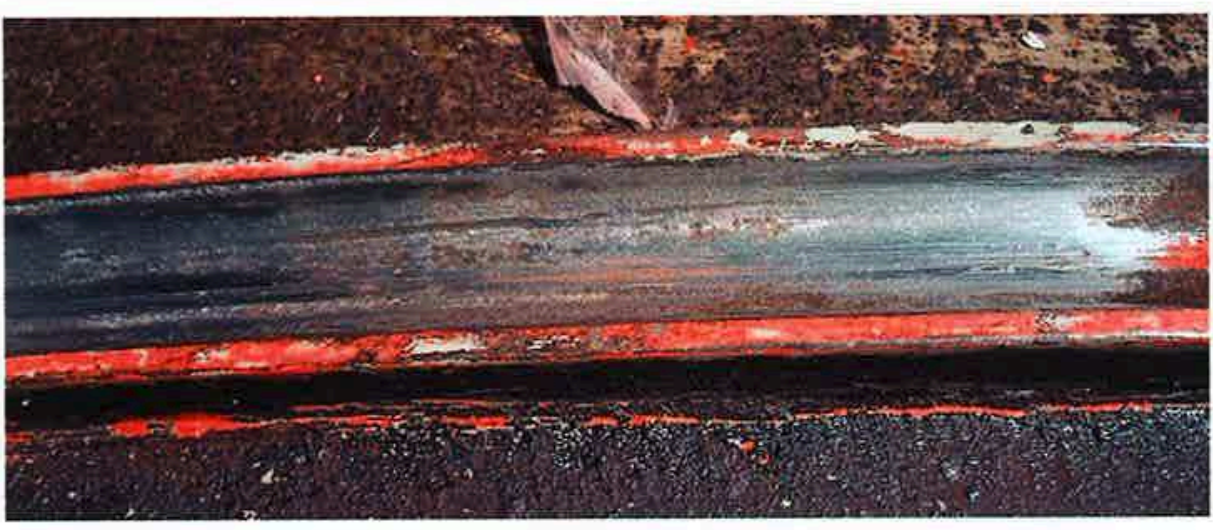

Fig. 5: Friction marks on the surface of the deflection shoe of support cable $B$ Bild 5: Reibspuren auf der Oberfläche des Ablenkschuhs von Tragseil B as well as on the broken profile wires, friction marks with scale-like build-ups could be discerned (Fig. 4). These friction marks of unknown origin could be found at all wire break locations.

Considerable friction marks were also found in rope direction at the four guide grooves of the top station. Bare spots in these areas indicate a high surface pressure (Fig. 5) About $60 \mathrm{~m}$ from the top station, the three support cables $A, C$, and D still intact were also characterized by areas with friction marks and scale-like build-ups.

Investigations on the car's running gear did not reveal any indications that the running gear or parts of it were getting in contac with the support cable or its profile wires.

\subsection{Fractographic Analyses}

With one exception (fatigue crack), the fracture surfaces of the examined wires of support cable B are characterized by macro scopic features of overload fractures where the crack always initiated at grooves, corrosion pits or scale-like build-ups on the wire surface (Fig. 6). The scanning electron microscope analysis of the fracture surface (Fig. 7) revealed four typical fracture zones:

- Zone 1 with a depth of 200-300 $\mu \mathrm{m}$ des ignates the crack initiation point (finely structured intergranular surface of the overload fracture's surface covered with corrosion products)
Seilabschnitt wie auch an den gebrochenen Profildrähten Reibspuren mit schuppenartigen Auftragungen erkennbar (Bild 4), Diese Reibspuren unbekannter Herkunft waren bei allen Drahtbruchstellen zu finden.

Erhebliche Reibspuren in Seilrichtung wurden auch bei den vier Führungsrillen der Berg station gefunden, Blanke Stellen in diesen Bereichen deuten auf hohe Flächenpressung hin (Bild 5). Die drei noch intakten Tragseile A, C und $D$ enthielten ebenfalls Bereiche mit Reibspuren und schuppenartigen Auftragungen ebenfalls ca. $60 \mathrm{~m}$ ausserhalb der Bergstation.

Untersuchungen am Fahrzeug-Laufwerk ergaben keine Hinweise darauf, dass das Fahrwerk oder Teile davon mit dem Tragseil oder deren Profildrähten in Berührung gekommen wären.

\subsection{Fraktographische Analysen}

Mit einer Ausnahme (Ermüdungsanriss) zeigten die Bruchflächen der untersuchten Drähte von Tragseil B makroskopische Merkmale von Gewaltbrüchen, stets mit Rissausgang be Riefen, Korrsionsnarben oder schuppenartigen Auftragungen an der Draht-Aussenseite (Bild 6). Die Bruchflächenanalyse im Rasterelektronenmikroskop (Bild 7) ergab vier typische Bruchzonen:

- Zone 1 mit einer Tiefe von 200-300 $\mu \mathrm{m}$ bezeichnet die Bruchausgangsstelle (fein fläche mit Korrosionsprodukten belegt);

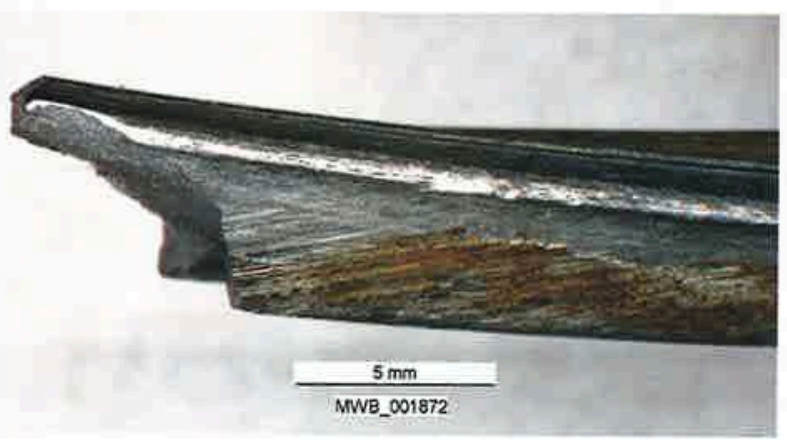

Fig. 6: Wire surface in the fracture area with grooves scale-like build ups, and corrosion products Bild 6: Drahtoberfläche im Bruchbereich mit Riefen, schuppenartigen Auftragungen und Korrosionsprodukten 


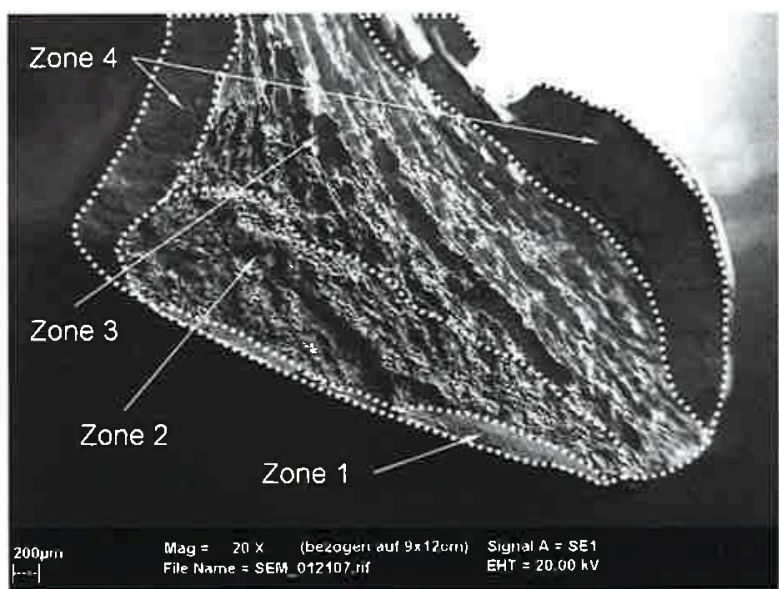

Fig. 7: Typical appearance of the wire fracture surfaces Bild 7: Typische Ausbildung der Draht-Bruchflächen
- Zone 2 is characterized by an intergranular fracture with partially wide open grain boundaries and a depth of a maximum of $700 \mu \mathrm{m}$ (Fig. 10);

- Zone 3 is characterized by a micro-ductile overload fracture with fine dimples and isolated cleavage planes (Fig. 11);

- Zone 4 is characterized by shear lips.

The fracture surfaces in zone 3 and zone 4 were not corroded. Hence, they formed only recently.

\subsection{Metallographic Analyses}

Longitudinal sections across the fracture surfaces parallel to the wire axis of four different wires consistently revealed numerous secondary cracks with a depth of 200 to $300 \mu \mathrm{m}$. They preferentially formed at corrosion pits and below scale-like build-ups (Fig. 8). In addition to that, areas with friction martensite as well as heat affected zones could be identified below these build-ups (Fig, 9), Microsections of wires of the support cables A, C, and D from areas exhibiting friction marks and scale-like build-ups are also characterized by incipient cracks such as in support cable B (Fig. 8). However, they had a depth of only approx. $100 \mu \mathrm{m}$.
- Zone 2 zeigt einen interkristallinen Bruch mit teilweise klaffenden Korngrenzen und einer Tiefe von maximal $700 \mu \mathrm{m}$ (Bild 10);

- Zone 3 weist die Struktur eines mikroduk tilen Gewaltbruches mit feinen Waben und vereinzelt ausgebildeten Spaltflächen auf (Bild 11);

- Zone 4 zeigt ausgebildete Scherlippen.

Die Bruchflächen in Zone 3 und Zone 4 waren nicht korrodiert und folglich erst vor kurzer Zeit entstanden.

\subsection{Metallografische Analysen}

Längsschliffe durch die Bruchflächen parallel zur Drahtachse an vier verschiedenen Drähten ergaben übereinstimmend zah|reiche Nebenrisse mit einer Tiefe von 200 bis $300 \mu \mathrm{m}$. Diese entstanden bevorzugt an Korrosionsnarben und unter schuppenartigen Auftragungen (Bild 8). Unter diesen Auftragungen (Bild 9) konnten zudem Bereiche mit Reibmartensit sowie Wärmeeinflusszonen identifiziert werden. Mikroschliffe an Drähten der Tragseile $A, C$ und $D$ aus Bereichen mit Reibspuren und schuppenartigen Auftragungen zeigten ebenfalls Anrisse wie bei Tragseil B (Bild 8), allerdings mit geringerer Tiefe von lediglich ca. $100 \mu \mathrm{m}$

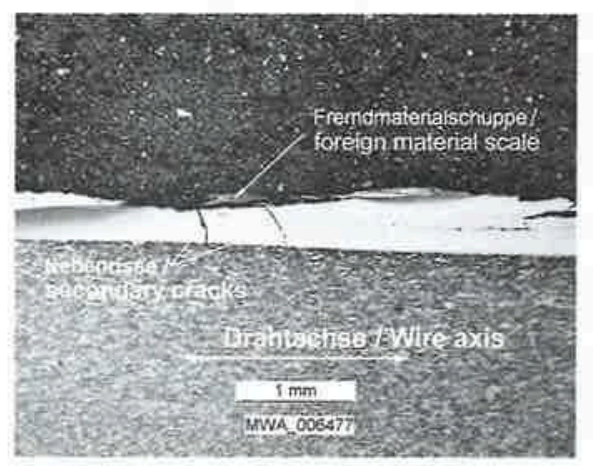

Fig. 8: Foreign material scale exhibiting secondary cracks

Bild 8: Fremdmaterialschuppe mit Nebenrissen

\subsection{Micro Area Analysis}

In order to clarify the origin of these scalelike build-ups, energy dispersive X-ray spectroscopy (EDX) and wavelength-dispersive $X$-Ray spectroscopy (WDX) analyses were performed on the wire, the scales', and the deflection shoe material of the top station.

Differences were found between the wire and the scale material with respect to the carbon and silicon content (wire: approx. $0.6 \% \mathrm{C}$ and $0.3 \%$ Si; scale: approx, $0.2 \% \mathrm{C}$

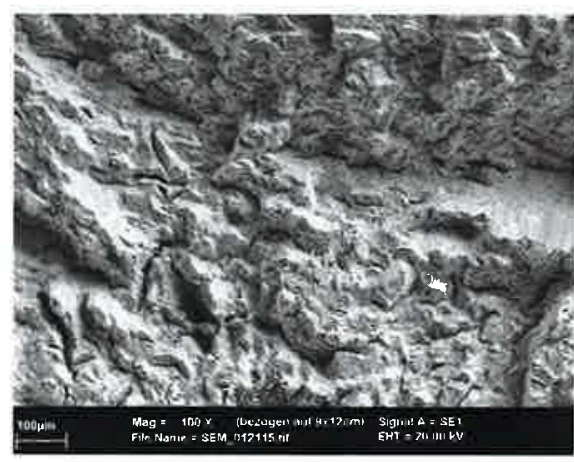

Fig. 10: Intergranular overload fracture with wide open grain boundaries (zone 2)

Bild 10: Interkristalliner Gewaltbruch mit klaffenden Korngrenzen (Zone 2)

Pract: Metallogr. 53 (2016) 12

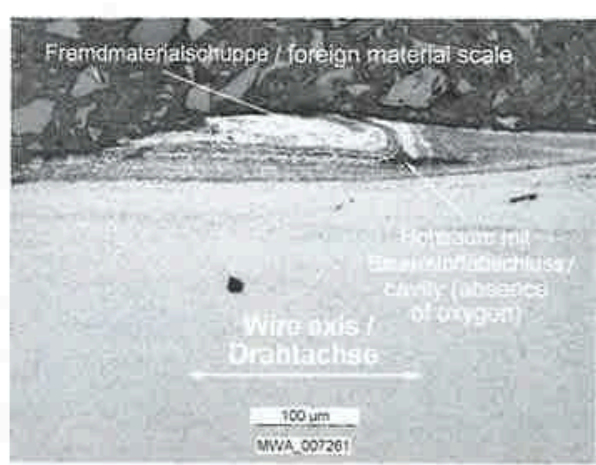

Fig. 9: Foreign material scale with cavity

Bild 9: Fremdmaterialschuppe mit Hohiraum

\subsection{Mikrobereichsanalysen}

Um die Herkunft dieser schuppenartigen Auftragungen abzuklären, wurden Analysen mittels energiedispersiver Röntgenanalytik (EDX) und mit wellenlängendispersiver Röntgenanalytik (WDX) am Draht-, Schuppen- und Ablenkschuh-Werkstoff der Bergstation durchgeführt.

Es zeigten sich Unterschiede zwischen Drahtund Schuppenwerkstoff bezüglich Kohlenstoff- und Siliziumgehalt (Draht: ca. 0.6\% C und $0.3 \%$ Si; Schuppe: ca. $0.2 \%$ C, Si nicht

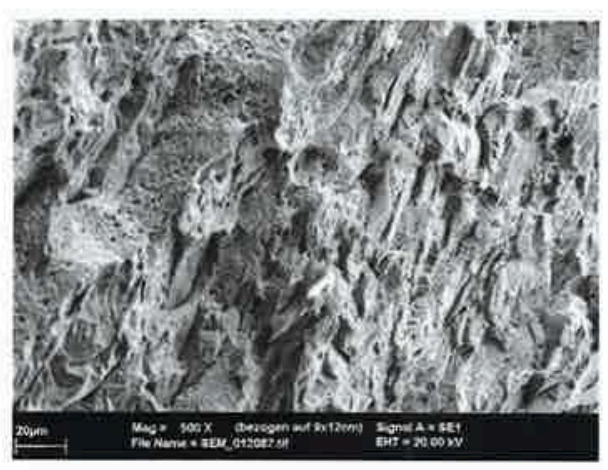

Fig. 11: Micro-ductile overload fracture with fine dimples (zone 3)

Bild 11: Mikroduktiler Gewaltbruch mit feinen Waben (Zone 3) 
Si below limit of detection). Hence, the wire and scale material were not identical. However, the results of both the analyses of the scale (Fig. 9) and the deflection shoe material (Fig. 5) are in agreement.

\subsection{Chemical Analyses}

Several chemical analyses were performed aiming at determining the corrosive potential of the used lubricating grease as well as of the deposits present on the support cable's surface.

Based on these analyses, the corrosion potential of these substances as well as of the support cable environment can be rated as low.

\subsection{Mechanical Testing of the Wire}

Mechanical testing (tensile tests, tests with bending back and forth, twisting tests) of profile wires from the damaged area with and without friction marks as well as of intact ref erence wires from the upper anchoring area did not reveal any negative influence of the corrosion condition on the mechanical parameters. However, for the samples exhibiting friction marks and scale-like build-ups the values obtained were partially considerably lower than those of the reference wires.

\section{Cause of the Damage}

All fracture surfaces (except for those exhibiting fatigue striations) showed features of an intergranular overload fracture in zone 2 (Fig. 10) and of a micro-ductile overload fracture in zone 3 (Fig. 11). As experience shows, the intergranular cracks identified during the fractographic examination (Fig. 10) are rare for the used profile wire material $\left(R_{m}=1600 \mathrm{MPa}\right)$ and only occur in cases of heat treatment errors and/or as a result of hydrogen embrittlement. The intergranular incipient cracks found reached considerably deeper into the wire materia than the friction martensite zones. Hence, hardening cracks could be excluded, Therefore, hydrogen embrittlement was moved into the focus as probable cause. Hydrogen nachweisbar). Draht- und Schuppenwerkstoff waren folglich nicht identisch. Dagegen timmten die Analyseergebnisse von Schuppen- (Bild 9) und Ablenkschuhwerkstoff
(Bild 5) überein.

\subsection{Chemische Analysen}

Mehrere chemische Analyseverfahren hatten zum Ziel, das korrosive Potential der verwendeten Schmierfette sowie der an der Tragseiloberfläche vorhandenen Ablagerungen zu bestimmen.

Die Analysen ergaben, dass das Korrosionspotential dieser Substanzen sowie der Tragseilumgebung als mild zu bewerten ist.

\subsection{Mechanische Drahtprüfungen}

Mechanische Prüfungen (Zugversuche, Hinund Herbiegeversuche, Verwindeversuche) an Profildrähten aus dem Schadensbereich mit und ohne Reibspuren sowie an intakten Referenzdrähten aus dem oberen Verankerungsbereich ergaben keine negative Beeinflussung der mechanischen Kennwerte durch den Korrosionszustand. Die Proben mit Reibspuren und schuppenartigen Auftragungen ergaben allerdings Kennwerte, die teilweise erheblich unterhalb derjenigen der Referenzdrähte lagen.

\section{Schadensursache}

Alle Bruchflächen (ausgenommen diejenige mit Ermüdungsschwingstreifen) zeigten Merkmale eines interkristallinen Gewaltbruches in Zone 2 (Bild 10) und eines mikroduktilen Gewaltbruches in Zone 3 (Bild 11). Die bei der fraktografischen Untersuchung festgestellten interkristallinen Risse (Bild 10) treten beim verwendeten Profildrahtwerkstoff $\left(R_{m}=1600 \mathrm{MPa}\right)$ erfahrungsgemäß selten und nur bei Wärmebehandlungsfehlern und/ oder infolge von Wasserstoffversprödung auf. Härterisse konnten ausgeschlossen werden, da die gefundenen, interkristallinen Anrisse erheblich tiefer in den Drahtwerkstoff reichten als die Reibmartensitzonen. Als wahrscheinliche Ursache rückte daher eine Wasserstoffversprödung in den Vordergrund. Wasserstoff aus from metallurgical or galvanic processes could be excluded, as no relevant indications could be found. Thus, diffusible hydrogen remained as potential cause of the crack, It forms during corrosion processes in the absence of oxygen

\section{Reconstruction of the Damage Progression}

During the first, jerky, cable shift in 1979 (according to the cable car personnel), a local heat- and/or deformation-induced martensite formation at the support cable surface as well as material transfer ("scales") due to local seizing occurred between the support cable and the deflection shoe in the top station owing to high surface pressure and insufficient lubrication, In the absence of oxygen below material build-ups and due to the permanent static tensile stresses in the support cable, the conditions for hydrogen induced stress corrosion could develop. Owing to the mild environment, the crack growth process took around 25 years, before the first wire broke due to exceeding the critical crack length. The redistribution of the load to adjacent wires which were also already weakened resulted in a chain reaction during which all profile wires broke in the friction-damaged area. It is thanks to the sufficient strength of the round wires of the cable remaining intact that the support cable did not break catastrophically.

\section{References / Literatur}

[1] Piskoty, G.; Zgraggen, M.; Michel, S.; Rössler, G.; Faller, M.; Oplatka, G.: Abklärung der Ursachen eines Tragseilschadens, EmpaBericht Nr. 437392, Dübendorf, Schweiz, 2005

[2] Zgraggen, $M_{\text {; }}$; Piskoty, G.; Faller, $M_{\text {.; }}$ Kovacs, G.; Rössler, G.; Michel, S.; Oplatka, G.; v. Trzebiatowski, 0.: Analysis of track rope damage in serious incident on Schilthorn aerial ropeway, Materials and Corrosion, 57 (2006) $7,549-554$ metallurgischen oder galvanischen Prozessen konnte ausgeschlossen werden, da keine Hinweise darauf gefunden wurden. Somit verblieb diffusionsfähiger Wasserstoff als potenzielle Rissauslöser. Dieser entsteht bei Korrosionsprozessen unter Sauerstoffabschluss.

\section{Rekonstruktion des Schadens-}

\section{verlaufes}

Während der ersten, gemäss Bahnpersona ruckartig erfolgten Seilverschiebung im Jahre 1979 kam es zwischen Tragseil und Ablenkschuh in der Bergstation durch hohe Flächenpressung und mangelhafte Schmierung zu lokaler wärme- und/oder verformungsinduzierte Martensitbildung an der Tragseiloberfläche sowie zu Materialübertrag ("Schuppen“) infolge örtlicher Verschweißungen. Unter Sauerstoffabschluss unterhalb von Materialauftragungen und durch die permanente, statische Zugspannung im Tragseil ergaben sich Bedingungen für eine wasserstoffinduzierte Spannungsrisskorrosion. Durch die milde korrosive Umgebung dauerte der Risswachstumsprozess rund 25 Jahre, ehe der èrste Draht durch Ũberschreitung der kritischen Risslänge brach. Infolge Lastumlagerung auf benachbarte, ebenfalls bereits geschwächte Drähte kam es zu einer Kettenreaktion, während der alle Profildrähte im reibgeschädigten Bereich brachen. Dass das Tragseil nicht katastrophal riss, ist der ausreichenden Restfestigkeit der intakt gebliebenen Runddrähte des Seiles zu verdanken.

[3] Piskoty,G.;Zgraggen, M.; Weisse, B.;Affolter, Chr.; Terrasi, G.: Structural failures of rope-based systems, Engineering Failure Analysis, 16 (2009) 1929-1939

DOl: 10.1016/j.engfailanal.2008.10.004

[4] Broichhausen, J.: Schadenskunde, Carl Hanse Verlag, München, Deutschland, 1985

[5] Lange, G.; Pohl, M.: Systematische Beurteilung technischer Schadensfälle, 5. Auflage Wiley-VCH Verlag GmbH \& Co. KGaA, Weinheim, Deutschland, 2001 
[6] VDI-Richtlinien 3822, Schadensanalyse Beuth-Verlag, Berlin, Deutschland, 1984

[7] Uhlig W.: Schadensanalyse, VEB-Verlag Technik, Berlin, Deutschland, 1986

\section{Roland E. Koller}

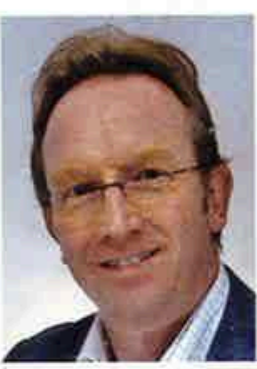

born on Decem-

ber $4^{\text {th }}, 1957$ in Bern,

Switzerland degreed

at the Swiss Federal

Institute of Technol-

ogy (ETH), Zürich as

a mechanical engi-

neer. After acquiring

practical experiences

as a rocket scientist he joined the Swiss

Federal Laboratories for Material Science and Technology (Empa). Currently he is head of the durability lab and lecturer at ETH

\section{Bibliography}

DOI 10.3139/147.110429

Pract. Metallogr. 53 (2016) 11; page 696-710

(C) Carl Hanser Verlag GmbH \& Co. KG

ISSN 0032-678X

\section{Gabor Piskoty}

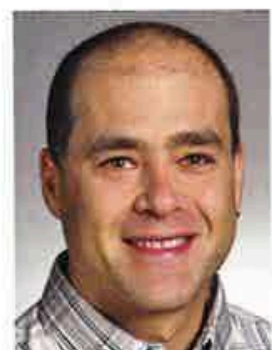

born on August 22nd

1966 in Budapest. Hun-

gary, degreed at the

TU-Budapest (BME) as

a mechanical engineer.

He wrote his $\mathrm{PhD}$ thesis about rope derailment

of monocable ropeways at the Swiss Federal

Institute of Technology

(ETH), Zürich, Since

1999 he is a failure analyst at the Empa, Düben$\operatorname{dorf}(\mathrm{CH})$

\section{COMPUTER | KUNSTSTOFFE | TECHNIK | WIRTSCHAET}

\section{HANSER}

Lernen Sie aus den Fehlern anderer!

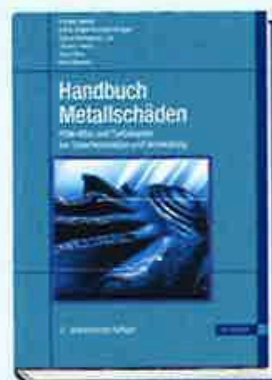

Neidel u.a.

Handbuch MeLallschāde

ISBN 978-3-446-42775-4 $\in 249,-$
Das Handbuch bietet Ihnen eine Zusammenstellung von mehr als 60 Original-Schadensfällen.

$\checkmark$ Ursachen, Abhilfernaßnahmen, Prävention

$\checkmark$ Exzellente optische Vergleichsmöglichkeiten

$\checkmark$ Detaillierte Tabellen der Werkstoffe

$\checkmark$ Schnelle Einordnung von Schadensfällen

durch umfangreichen REM-Bildatlas

Weitere Informationen und

Bestellmōglichkeit im Internet

unter www.hanser-fachbuch.de

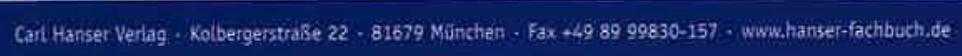

